\title{
Predictive factors of breast cancer evaluated by immunohistochemistry
}

\author{
Fatores preditivos do câncer de mama avaliados pela imuno-histoquímica
}

Helenice Gobbi'; Rafael Malagoli Rochaa ${ }^{2}$ Cristiana Buzelin Nunes ${ }^{3}$

\section{key words Estrogen receptor Progesterone receptor Her2/neu}

\section{abstract}

Hormone receptor and Her2 protein overexpression evaluated by immunohistochemistry (IHC) is widely validated as a predictive factor in breast cancer. The quality of the IHC reaction is influenced by tissue fixation and processing. Over- and underfixation deeply affect IHC results. Antigen retrieval may improve IHC but it does not recover tissue from autolysis or overfixation. The choice of primary antibody for IHC as to its sensitivity and specificity in relation to therapeutic response represents an important stage. Apart from mouse monoclonal antibodies, new rabbit monoclonal antibodies are commercially available, such as clones anti-ER SP1 and B644, anti-PR SP2 and B645 and anti-Her2 SP3 and 4B5. They represent an alternative to hormone receptor and Her2 evaluation by IHC. New polymeric nonbiotinylated detection systems are also available and allow accurate and strong marking with no stromal and no non-specific cytoplasmic staining due to endogenous biotin. The most recommended cut off for estrogen and progesterone receptors (ER and PR) is more than $1 \%$ of positive cells with moderate or strong staining intensity (Allred's scoring system). New guidelines for Her2 evaluation by IHC show a cut off of more than $30 \%$ of positive cells with strong intensity (3+) that correlates better with gene amplification. The $2+$ cases are now considered indeterminate and should be confirmed by fluorescence in situ hybridisation (FISH) or chromogenic in situ hybridisation CISH. A quality control of pre-analytical, analytical and post-analytical phases of IHC is recommended in order to optimize results.

\section{resumo}

A superexpressão de receptores hormonais e Her2 avaliada pela imuno-histoquímica (IHQ) é amplamente validada como fator preditivo em câncer de mama. A qualidade da reação imuno-histoquímica é influenciada pela fixação do tecido e seu processamento. A fixação insuficiente ou demasiada afeta profundamente os resultados da IHQ. A reativação antigênica pode melhorar os resultados da IHQ, porém não recupera tecidos com autólise ou com excessiva fixação. A escolha do anticorpo primário para a IHQ, considerando sua sensibilidade e sua especificidade de acordo com a resposta terapêutica, representa uma importante etapa. Além de anticorpos monoclonais de camundongo, novos anticorpos monoclonais de coelho são comercialmente disponíveis, tais como clones SP1 e B644 anti-RE, SP2 e B645 anti-RP, e SP3 e 4B5 anti-Her2. Eles representam uma alternativa para avaliação de receptores hormonais e Her2 através da IHQ. Novos sistemas de detecção poliméricos nãobiotinilados também são disponíveis e permitem marcação exata e forte sem marcação estromal ou citoplasmática inespecífica devido à biotina endógena. O cut off mais recomendado para receptor de estrogênio (RE) e receptor de progesterona (RP) é acima de 1\% de células positivas com marcação moderada ou forte (sistema de escore de Allred). Novas recomendações para avaliação de Her2 através da IHQ apontam um cut off de mais de $30 \%$ de células positivas com marcação forte (3+), que melhor se relaciona com amplificação gênica. Os casos $2+$ são agora considerados indeterminados e devem ser confirmados por hibridação in situ por fluorescência (FISH) ou hibridização in situ colorimétrica (CISH). Um controle de qualidade de fases pré-analítica, analítica e pós-analítica da IHQ é recomendado para a otimização dos resultados. unitermos

Receptor de estrógeno

Receptor de progesterona

Her2/neu

1. Master degree and doctorate in Pathology; associate professor of Anatomic Pathology, Faculdade de Medicina da Universidade Federal de Minas Cerais (UFMG).

2. Master degree and doctorate student in Ceneral Pathology, Faculdade de Medicina da UFMG.

3. Master degree in Medical Pathology, Faculdade de Medicina da UFMG.

This work was carried out at the laboratory of breast pathology of Faculdade de Medicina da UFMG, and financially supported by Fundação de Amparo à Pesquisa do Estado de Minas Cerais

(FAPEMIG), Conselho Nacional de Desenvolvimento Científico e Tecnológico (CNPq), and Coordenação de Aperfeiçoamento de Pessoal de Nível Superior (CAPES). 


\section{Introduction}

Prognostic factors are clinic, pathologic, and biologic features of cancer patients and their tumors that forecast clinical outcome, i.e. the likelihood of disease recurrence or patient survival, in an untreated setting. Predictive factors, in contrast are clinic, pathologic, and biologic features that are used to estimate the likelihood for a response to a particular type of adjuvant therapy ${ }^{(1,15)}$. Pathologists measure and interpret certain prognostic and predictive factors of breast cancers. Oncologists use the results supplied by pathologists in combination with other important information to make decisions about the treatment of their patients ${ }^{(1,15)}$.

To be useful a predictive factor should be technically and clinically validated and should influence clinical decision-making. Technical validation means that the assay used to measure the factor is sensitive, specific, reproducible, and interpreted in a uniform manner from laboratory to laboratory. Clinical validation means that the test identifies subsets of patients with significantly different risks for recurrence, survival or treatment response that are independent from other factors $(1,15)$.

Although predictive factors of therapy response have more clinical value, the only broadly validated predictive factors for the routine clinical use are estrogen (ER) and progesterone (PR) receptors and Her ${ }^{(3)}$.

The immunohistochemical technique for hormone receptors and Her2 evaluation in breast cancer will be discussed along this review including tissue processing, antigen retrieval, choice of primary antibody and detection system, and evaluation of immunostaining.

\section{Estrogen and progesterone receptors}

Hormone receptors exert their physiological effects of regulating the proliferation and differentiation of normal breast epithelium by binding to estrogen receptors, which are members of the nuclear receptor superfamily of ligandinducible transcription factors ${ }^{(1)}$. The estrogen receptor $(E R) \alpha$ regulates the differentiation and maintenance of neutral, skeletal, cardiovascular, and reproductive tissues. Compounds that modulate ER $\alpha$ transcriptional activity are currently being used to treat osteoporosis, cardiovascular disease, and breast cancer ${ }^{(21)}$. All ER $\alpha$ ligands bind exclusively with the C-terminal ligand-binding domain. Synthetic ligands such as tamoxifen and raloxifene belong to a growing class of molecules known as selective estrogen receptor modulators (SERM), which function as antagonists in specific tissue and promoter contexts ${ }^{(37)}$.
The discovery of a second $E R$, termed $\operatorname{ER} \beta^{(37)}$, indicates that the mechanism of action of estrogens is more complex than anticipated. Human ER $\beta$ has a structure highly homologous to the previously known ER $\alpha$. ER $\beta$ is expressed by normal ductal epithelium and a majority of breast cancers ${ }^{(26)}$. ER $\beta$ positive breast cancers are predominantly ER $\alpha$ and PR-positive, node negative, well differentiated and slowly proliferating. The coexpression of ER $\beta$ with ER $\alpha$ and PR as well as its association with indicators of low biological aggressiveness suggest that ER $\beta$-positive tumors are likely to respond to hormonal therapy. The independent predictive value of $E R \beta$ remains to be established ${ }^{(26)}$.

PRs are ligand-activated transcription factor members of the steroid hormone family of nuclear receptors. They exist naturally as two isoforms, PR-B and PR-A, transcribed from two promoters on a single gene ${ }^{(14)}$. Molecular basis for functional differences between both PR isoforms demonstrate that in breast cancer cells, although some genes are regulated by progesterone through both PR isoforms, most genes are uniquely regulated through one or the other isoform and predominantly through PR-B ${ }^{(14)}$. In breast cancers, total PR levels are routinely measured as a guide to hormone therapy and as markers of disease prognosis together with $\mathrm{ER}^{(43)}$.

ER may be the best example of a tumor biomarker with an assay that drives therapeutic decision-making. Since ER and PR represent a well established predictor of response to endocrine therapy in breast cancer, their measurements improve the predictive value further by defining the ERpositive/PR-negative tumor type, which is less likely to respond to therapy than tumors that are positive for both receptors ${ }^{(1)}$. ER and PR assays have been routinely used in the selection of appropriate therapy for breast cancer patients for more than 30 years ${ }^{(1)}$. However, it is well known that up to $30 \%$ to $40 \%$ of breast tumors with positive hormone receptor status do not respond to endocrine therapy ${ }^{(15)}$. Reasons for the lack of response have remained poorly understood, although steroid-independent growth factor signaling (e.g. via HER-2/neu), functionally deficient splicing variants of the ER gene ${ }^{(15)}$, and heterogeneity of ER expression ${ }^{(28)}$ may partly explain poor therapy outcome of ER-positive tumors.

\section{ER and PR antibodies}

Up to the last decade, quantification of ER and PR was made by biochemical methods that consist of a dextranecoated charcoal assay (DCC) and a minimum of $0.5 \mathrm{~mm}^{3}$ 
of the extirpated tumor was necessary. The cut-off point for positivity/negativity was generally established at $10 \mathrm{fmol} /$ mg cytosol protein ${ }^{(15)}$. With the development of monoclonal antibodies against nuclear estrogen and progesterone nuclear epitopes, immunohistochemical measurements have been increasingly validated by several studies ${ }^{(1,15}$, ${ }^{23)}$. Since 1990, ER and PR have been evaluated almost exclusively by immunohistochemistry, using formalin-fixed paraffin-embedded tissue samples.

The most used antibodies for ER and PR evaluation by immunohistochemistry in formalin-fixed paraffinembedded tissue have been the mouse monoclonal antibodies, including clones 1D5 and 6F11 anti-ER and the PgR 636 and PgR 312 anti-PR. Recently, a new generation of rabbit monoclonal antibodies has been developed and is commercially available, such as clones SP1 and B644 anti-ER and SP2 and B645 anti-PR ${ }^{(24,25,46)}$. The technology to prepare these antibodies from a single hybridoma allows the production of antibodies with high sensitivity and specificity, high working dilutions and better cost versus benefits. Results from comparative studies have shown that the rabbit clone SP1 may be more sensitive than clone 1D5 and has the same specificity as clone 1D5 in immunohistochemistry(24).

The new rabbit antibody SP1 and the mouse antibody 1D5 were recently evaluated and compared to the biochemical ER assay results and clinical data on survival and adjuvant systemic therapy. The authors detected $69.5 \%$ positivity when using the rabbit SP1 and $63.1 \%$, using the mouse antibody 1D5. Rabbit antibody SP1 was also a better independent prognostic factor than 1D5 in multivariate analysis, including age, tumor size, grade, lymphovascular invasion, and nodal status. SP1 was considered by the authors an improved standard for ER immunohistochemistry assessment in breast cancer ${ }^{(8)}$.

The rabbit monoclonal antibodies against ER and PR were also evaluated on alcohol-fixed smears of breast cancers obtained by fine needle aspiration biopsy. The results showed advantages, such as high sensitivity and specificity of the reaction, stronger immunostaining and shorter procedure times ${ }^{(6)}$. The rabbit antibodies appear to offer increased sensitivity with no apparent loss of specificity and allow a higher working dilution (24).

We carried out a study evaluating new rabbit monoclonal antibodies anti-ER (SP1 and B644) and anti-PR (SP2 and B645), comparing them to mouse antibodies anti-ER (1D5 and 6F11) and anti-PR (PgR 636 and PgR 312). Our results showed that the rabbit antibodies could be used in higher working dilutions when using antigen retrieval (Figure 1). They represent an alternative for estrogen and progesterone receptor evaluation in clinical tests ${ }^{(44,45)}$.

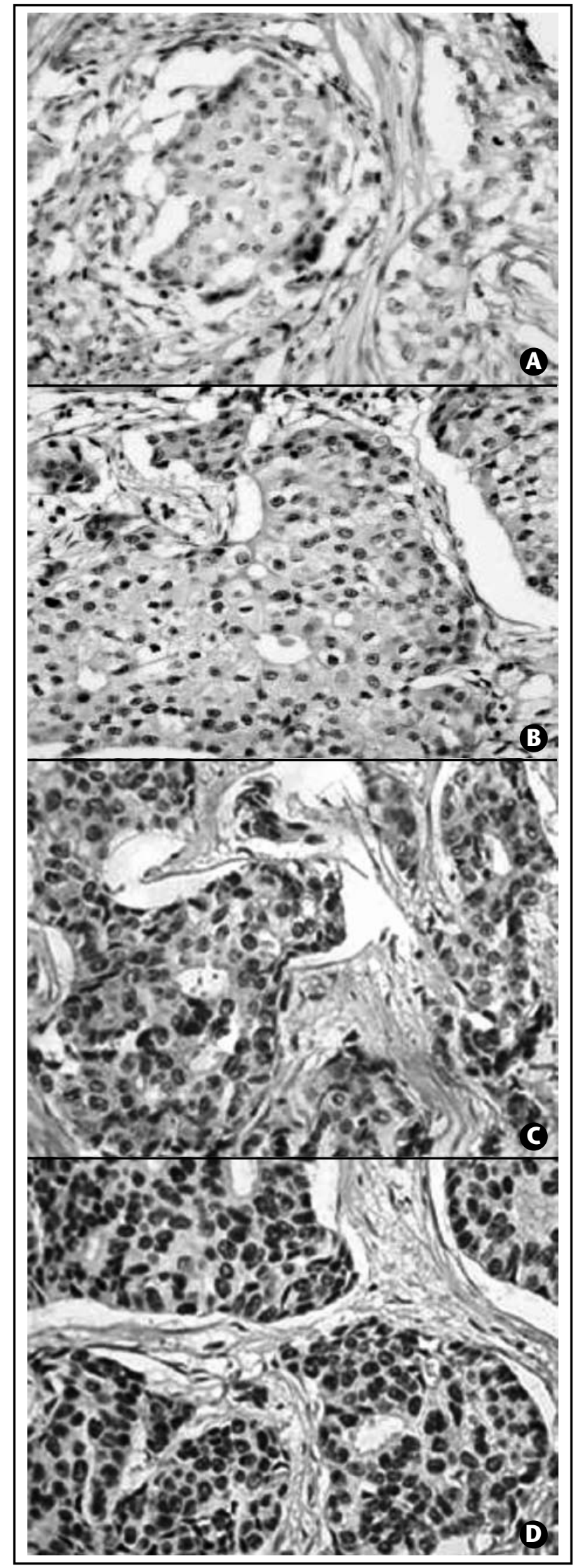

Figure 1 - Immunohistochemical staining carried out in our laboratory in the same tumor: ER and PR staining using mouse monoclonal antibodies anti-ER, clone 1D5 (A); and anti-PR, clone PgR $636(C)$; and rabbit monoclonals anti-ER, clone SP1 (B); and anti-PR, clone SP2 (D) 


\section{Interpretation of ER and PR immunostainings}

ER and PR staining interpretation and cut off rely basically on subjective visual estimates, yielding only qualitative or at best semi-quantitative results. New studies have applied semi-quantitative scores to assess nuclear staining intensity as a marker of the number of receptors per cell(1,15). Although in some cases a cytoplasm staining is demonstrated, its biological or clinical meaning is not well established, and only nuclear staining has been considered(5). Diverse computerized image analysis systems have been employed and were found to correlate well with semi-quantitative visual scoring methods and with biochemical data. However, the high cost and the complexity of these image analysis systems, requiring major hardware and software investments, severely limit their practicability in routine diagnostic laboratory ${ }^{(11,31)}$.

The initial studies that validated the assessment of ER by immunohistochemistry established a cut off of $10 \%$ positivity that correlates to $10 \mathrm{fmol} / \mathrm{mg}$ of protein detected by biochemical method. The $10 \%$ level for positivity, independent on the staining intensity, has been accepted and has been the most used cut off for ER and $\mathrm{PR}^{(15,17}$ 48). However, further studies showed that patients whose tumors expressing ER in more than 1\% of neoplastic cells with moderate or strong intensity presented response to anti-estrogen therapy ${ }^{(1,20)}$. The 2005 Saint Gallen Consensus Conference recommended the cut off proposed by Allred (Table) in which a total score of more than 3 is considered positive $^{(18)}$.

\section{Her2/neu}

HER2 gene (c-erbB-2 or HER2-neu) is a human analogue of the gene neu identified in rat neuroblastomas. The protooncogene HER2 is located on chromosome 17 and encodes a 185-kd transmembrane glycoprotein with tyrosine-kinase activity, which is a member of the epithelial HER family that also includes the epidermal growth factor receptor (EGFR) or HER1, HER3 and HER4. Normal cells and the majority of breast cancers carry two copies of the HER2 gene on chromosome 17 and express low levels of p185 (Her2 protein) ${ }^{(7,9,13,15)}$. HER2 gene amplification or protein overexpression is seen in approximately $20 \%$ to $30 \%$ of invasive breast cancers in humans, most commonly in high-grade invasive ductal carcinomas $(2,9,15,41)$.

Studies have reported an association with Her2 overexpression and other adverse prognostic factors, such as positive lymph nodes, larger tumor size, high histological grade, high proliferation rate, and lack of expression of estrogen and progesterone receptors ${ }^{(15,40)}$. But the importance of this gene is higher as a predictive than a prognostic factor. The overexpression of Her2 is implied in the resistance to tamoxifen and the chemotherapy with cyclophosphamide, metothrexate and 5 -fluorouracil. Therefore, breast cancers with Her2 overexpression are more sensitive to antracyclines, specifically to trastuzumab. There is resistance to tamoxifen, but replacing of tamoxifen with aromatase inhibitors in patients with breast cancer ER and Her2 positive have demonstrated promising clinical results ${ }^{(7,9)}$. The American Society of Clinical Oncology (ASCO) Tumor Marker Guidelines Panel has recommended routine testing of HER2 on newly diagnosed and metastatic breast cancer since $2001^{(7,33)}$.

Different techniques have been used to assess the Her2 status in biopsies and surgical specimens, but currently the most frequently used methods are immunohistochemistry (IHC) to assess Her2 protein overexpression and in situ hybridisation to assess HER2 gene amplification ${ }^{(29,34,41)}$.

$\mathrm{IHC}$ is relatively easy to perform, has a short turnaround time and relatively low cost. However, immunohistochemical analysis is highly influenced by technical procedures, such as fixation affecting the quality of antigen epitopes in the formalin-fixed paraffin-embedded (FFPE) tissue samples

\begin{tabular}{|c|c|c|c|c|c|}
\hline \multirow{3}{*}{$\begin{array}{ll}\text { Table } & \begin{array}{c}\text { Allr } \\
\text { inte }\end{array} \\
\text { Intensity score }\end{array}$} & \multicolumn{5}{|c|}{$\begin{array}{l}\text { Allred's scoring system for ER evaluation in breast carcinomas obtained by the combination of } \\
\text { intensity and proportion of stained tumor nuclei* }\end{array}$} \\
\hline & & & portion score & & \\
\hline & 0 & $>0$ to 10 & $>10$ to 33 & $>33$ to 66 & $>66$ to 100 \\
\hline Weak & 0 & 2 & 4 & 5 & 6 \\
\hline Intermediate & 0 & 3 & 5 & 6 & 7 \\
\hline Strong & 0 & 3 & 6 & 7 & 8 \\
\hline
\end{tabular}

${ }^{*} A$ total score (TS) is obtained combining scored proportion plus intensity score. A TS of 0 to 2 is considered negative and a TS of 3 to 8, positive ${ }^{(1,23)}$. 
and choice of IHC reagents and protocols. Selection of specific antibodies and scoring methods are very important parameters for the accurate evaluation of protein expression $^{(21,41,43,52)}$. The HercepTest ${ }^{T \mathrm{~T}}$ kit has overcome some of these problems by using standardized methodology and reagents and by the inclusion of cell line controls. However, the reported sensitivity and specificity vary between different centres. The HercepTest ${ }^{\mathrm{TM}}$ kit is more expensive and shows more false positive cases than other monoclonal antibodies ${ }^{21,}$ 35). Despite the commercially variety of IHC antibodies available, there is no consensus about the best antibody for Her2 testing. The most common used antibodies for HER2 testing have been the HercepTest ${ }^{\text {TM }}$ and A0485 (rabbit polyclonal antibody), and the CB11 and TAB250 (mouse monoclonal antibodies). Recently, a new generation of rabbit monoclonal antibodies was released including the anti-Her2 rabbit clone SP3 (LabVision $\left.{ }^{\mathrm{TM}}\right)$ and 4B5 $\left(\text { Ventana }^{\mathrm{TM}}\right)^{(24)}$.

Several in situ hybridisation techniques are available to evaluate the HER2 gene amplification. Fluorescence in situ hybridisation (FISH) is thought to be an accurate technique for quantitative evaluation of HER2 gene status in breast cancer cells. FISH methodology requires a fluorescence microscopy equipped with high quality immersion objectives and fluorescence filters. As the fluorescence signals can fade within several weeks, the hybridisation results must be recorded with digital cameras or modern scanner systems. Therefore, analysis and recording of FISH data is expensive and time consuming. Most important, tissue section morphology is not optimal in FISH on FFPE, a particular problem in distinguishing invasive breast cancer and intraductal carcinoma ${ }^{(50,53)}$. To overcome these practical limitations, chromogenic in situ hybridisation (CISH) has been introduced, in which the DNA probe is detected using a simple immunohistochemical-like peroxidase reaction ${ }^{(56)}$. CISH is faster to analyse than FISH, does not require any equipment other than those used in routine histopathology laboratories, and allows for a simultaneous analysis of gene copy number and histological features of the lesions ${ }^{(4,49,54)}$. CISH has been validated and compared to FISH, with a high concordance rate. $\mathrm{CISH}$ is reported to have the same accuracy of FISH when a high level amplification is detected, and 93\%-99\% agreement when low level of amplification is detected ${ }^{(4,12)}$. In case of low-level amplification, some authors suggest that $\mathrm{CISH}$ chromosome 17 probe should be used, or dual probe FISH is recommended for confirmation ${ }^{(4)}$.

The most common scoring system for Her 2 overexpression has been that recommended in the HercepTest ${ }^{\mathrm{TM}}$ manufacturer's protocol ${ }^{(10)}$. This immunohistochemical Her2 scoring is based on the proportion and the intensity of cell membrane staining. But inter and intraobserver variations have been demonstrated on determination of Her2 overexpression, especially on intermediate categories ${ }^{(38)}$. When IHC results are compared with those obtained by FISH analysis, it appears that the IHC technique is associated with a significant number of false positives, particularly those represented by grade $2+$ scored using the HercepTest system ${ }^{(21)}$.

Given the rather poor predictive value of weakly positive results by IHC, two new consensus (UK Guidelines and the ASCO/College of American Pathologists [CAP] recommendations for Her2 testing in breast cancer) considered that immunohistochemistry for Her2 protein overexpression represents a valuable screening test. The ASCO/CAP guidelines proposed that cases interpreted as grade $2+$ should be considered as indeterminate or borderline, and not weakly positive. Strongly positive (3+) and completely negative (0) results appear to correlate well with gene amplification status ${ }^{(2,19,21)}$, but in situ hybridization should confirm all $2+$ results ${ }^{(13,54,55)}$. Only the invasive component of a tumor (not in situ disease) should be scored. For IHC, membranous reactivity only should be considered positive in a good quality assay. Her2 staining should not be observed in adjacent stroma or inflammatory cells, nor should benign epithelium show membranous reactivity. If staining is observed in benign components, the assay may be considered indeterminate; reporting should include an estimate of the percentage of immunopositive invasive cancer cells $\boldsymbol{s}^{(13,30,51)}$.

A threshold of more than $30 \%$ of tumor (rather than the originally specified $10 \%$ of the HercepTest) should show strong complete or circumferential membrane staining for a positive result. When less than $30 \%$ of the cells show circumferential staining, the result is considered indeterminate or equivocal and the tumor subjected to confirmatory FISH testing ${ }^{(27)}$. The visualization of a "train track" pattern that results from the staining apposing cell membranes has also been emphasized ${ }^{(32)}$. A cut off of more than $30 \%$ reflects the cumulative experience that usually a high percentage of the cells will be positive if it is a true IHC $3+$, compared to the cut-off values higher than $10 \%$. The goal of the $30 \%$ cut off is to decrease the incidence of false positive $3+^{(54)}$.

The ASCO/CAP Conference recommends for Her2 testing in breast cancer that HER2 status should be determined for all invasive breast carcinomas. A positive Her2 result is IHC 
staining of $3+$ (uniform, intense membrane staining of $>$ $30 \%$ of invasive tumor cells), a FISH result of more than six HER2 gene copies per nucleus, or FISH ratio (HER2 gene signals to chromosome 17 signals) of more than 2.2. A negative result is an IHC staining of 0 or $1+$, a FISH result of less than 4.0 HER2 gene copies per nucleus, or FISH ratio of less than 1.8. Equivocal results require additional action for final determination ${ }^{(22,54)}$.

In our laboratory, we compared the "sensitivity" and "specificity" of SP3 with those of mouse monoclonal and rabbit polyclonal antibodies to detect Her2. We also compared the immunohistochemical protein overexpression of protein with the gene amplification using $\mathrm{CISH}^{(20,38,39)}$. The antibody SP3 displayed an optimal "sensitivity", similar to that obtained with anti-Her2 polyclonal antibodies (i.e. HercepTest and A0485) when comparing IHC with CISH results. The SP3, HercepTest and A0485 identified all cases with HER2 amplification using the current guidelines for Her2 assessment. However, the SP3 and the polyclonal antibodies, including the HercepTest, detected more false-positive cases than mouse monoclonal antibodies CB11 and 4D5 ${ }^{(20,38,39)}$.

In our experience, SP3 shows higher sensitivity than mouse monoclonal antibodies (Figure 2). However the HercepTest, CB11 and 4D5 show higher "specificity" than SP3 for the identification of HER2 gene amplification ${ }^{(20,38)}$. Ricardo et al. ${ }^{(43)}$ also compared SP3 with CB11, having CISH as the gold standard in breast cancer tissue microarrays, however they showed a high specificity and a moderate sensitivity of SP3 ${ }^{(43)}$. We also evaluated interobserver variation in Her2 interpretation in IHC slides. The quality of immunostainings and the experience of the observers influence Her2 evaluation in tissue sections ${ }^{(38)}$.

\section{Limitations of predictive factors evaluation in breast cancer by immunohistochemistry in formalin- fixed paraffin-embedded tumors}

The success of immunohistochemistry is largely a result of a development of reliable markers for ER, PR and Her2 and of highly sensitive detection procedures. However, pre-analytical factors, such as unsatisfactory tissue fixation (under- or overfixation), a common problem in Brazil, represent an important drawback in immunohistologic evaluation of the neoplasia. Formalin has several advantages over alcohol, particularly the superior preservation of morphological detail. A major cause of variation in the

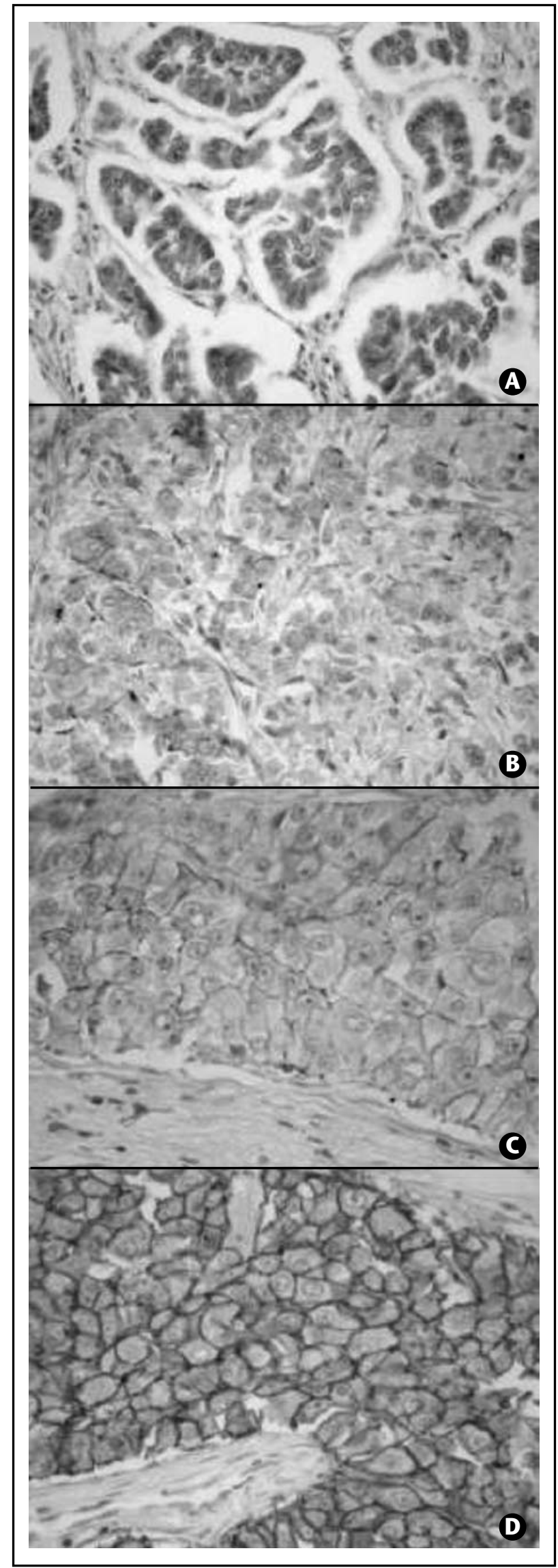

Figure 2 - Immunohistochemical staining carried out in our laboratory: Her2 staining using rabbit monoclonal SP3: $0(A) ; 1+(B) ; 2+(C) ; 3+(D)$ 
reproducibility of immunohistochemical staining is induced by tissue fixation and, to a lesser degree, tissue processing. Most laboratories in USA use neutral-buffered formalin (10\%) for tissue fixation that introduces cross-links, whereas coagulative fixatives are less popular ${ }^{(42)}$. However, in Brazil the use of buffered formalin is not a routine in the majority of the laboratories. Problems with formalin fixation comprise delay of fixation and variations in time of fixation. Overfixation leading to antigen masking probably through aldehydic linkage between proteins and formalin, and long-term storage of sections on slides before staining have been blamed for false-negative results ${ }^{(51)}$.

One of the challenges of immunohistochemistry is to develop methods that reverse changes produced during fixation such as high-temperature heating using the most suitable buffered solution. High-temperature heating is the most important factor for retrieval of antigens masked by formalin fixation. Higher temperature in general yields better results of antigen retrieval. Different heating methods have been used for antigen retrieval, such as autoclaving, pressure cooking, water bath, microwaving plus plastic pressure cooking, and steam heating. The temperature achieved by these methods appears to be the critical variable ${ }^{(47)}$.

Although the antigen retrieval step is more time consuming, the total cost of each test drops greatly when this technique is used. For example, the rabbit monoclonal antibody SP1 can be used 10 times less concentrated than the $6 \mathrm{~F} 11$ when using antigen retrieval ${ }^{(6)}$. However, antigen retrieval may cause false-positive stains or nonspecific background due to endogenous biotin. Although problems with endogenous biotin have previously been negligible in formalin-fixed tissue, antigen demasking also makes endogenous biotin more accessible ${ }^{(5,47)}$. High temperature, long heating time and high $\mathrm{pH}$ of the retrieval solution also increase the reactivity of endogenous biotin although they give the most efficient epitope retrieval ${ }^{(5,}$ 47). In our experience, the antigen retrieval for $E R$ and $P R$ using high $\mathrm{pH}(\mathrm{EDTA}, \mathrm{pH}=9)$ increases the reactivity, but also produces more non-specific and background staining. Different alternatives to avoid or reduce the effects of biotin/peroxidase are offered by different methods from different suppliers. Antigen retrieval methods have been improved $^{(5)}$ and more sensitive non-biotin polymeric detection systems for the antigen-antibody reaction have also been developed ${ }^{(39)}$.

A generation of polymer-based, biotin-free detection reagent is based on polymeric technology, which uses compact enzyme-antibody conjugates resulting in markedly increased penetrative ability of the reagent with improved detection sensitivity and efficiency ${ }^{(39)}$. Besides allowing cheap immunohistochemical assays - as the cost per test can be the same or even better than the nonpolymeric detection systems - the high dilutions of the primary antibody achieved by the polymeric conjugate detection systems also enable more reliable results to be obtained $^{(16)}$. High dilutions prevent background staining, formation of electrostatic or other non-immunological nonspecific bonds, or unexpected cross reactivities (especially with polyclonal antibodies) ${ }^{(36,39)}$. In our laboratory, we compared the new polymer detection systems with the streptavidin-biotin system in the assessment of ER in breast carcinomas. Our results showed that staining intensity of non-biotinylated polymeric detection systems is superior compared to conventional streptavidin-biotin detection system. Background and non-specific cytoplasm staining was also lower or completely absent when using the nonbiotinylated polymeric systems ${ }^{(45)}$.

\section{Take-home messages}

1. Fixation: cut sections of breast carcinoma should be fixed in buffered formalin for no longer than 24 hours. Under- and overfixation deeply affect immunohistochemical results.

2. Antigen retrieval: may improve $\mathrm{IHC}$, but is not a magic tool to recover autolysis or overtime fixation. The most common methods are heat-induced epitope retrieval in citrate buffer $(\mathrm{pH}=6)$ or EDTA $(\mathrm{pH}=9)$. High $\mathrm{pH}$ improves antigen retrieval, but also increases background and nonspecific cytoplasmic staining.

3. Choice of primary antibody: besides mouse monoclonal antibodies, novel rabbit monoclonals are available, allow high working dilutions and are cost effective.

4. Immunodetection systems: novel non-biotinylated polymer detection systems represent an alternative to the streptavidin-biotin systems. They show high staining intensity, low background and non-specific cytoplasmic staining. They allow higher working dilution of primary antibody than streptavidin-biotin systems.

5. Interpretation of immunohistochemistry - the recommended cut offs are:

- ER and PR Allred's scoring system is recommended. Tumors with more than $1 \%$ of positive cells with moderate or strong staining (total score $\geq 3$ ) are considered positive;

- Her2: tumors with $>30 \%$ of neoplastic cells showing strong complete circumferential staining are considered 
positive. When $<30 \%$ of cells show strong circumferential staining, the result is considered indeterminate and should be confirmed by FISH or CISH;
- quality control: laboratories should carry out quality control of pre-analytical, analytical and post-analytical phases of IHC in order to optimize quality and reproducibility of results.

\section{References}

1. ALLRED, D. C. et al. Prognostic and predictive factors in breast cancer by immunohistochemical analysis. Mod Pathol, v. 11, n. 2, p. 155-68, 1998.

2. BANKFALVI, A. et al. Comparative methodological analysis of erbB-2/HER-2 gene dosage, chromosomal copy number and protein overexpression in breast carcinoma tissues for diagnostic use. Histopathology, v. 37, n. 5, p. 411-19, 2000.

3. BARNES, D. M. et al. Immunohistochemical determination of oestrogen receptor: comparison of different methods of assessment of staining and correlation with clinical outcome of breast cancer patients. Br J Cancer, v. 74, n. 9, p. 1329-30, 1996.

4. BHARGAVA, R.; LAL, P.; CHEN, B. Chromogenic in situ hybridization for the detection of HER-2/neu gene amplification in breast cancer with an emphasis on tumors with borderline and low-level amplification: does it measure up to fluorescence in situ hybridization? Am J Clin Pathol, v. 123, n. 2, p. 237-43, 2005.

5. BOENISCHT, T. Formalin-fixed and heat-retrieved tissue antigens: a comparison of their immunoreactivity in experimental antibody diluents. Appl Immunohistochem Mol Morphol, v. 9, p. 176-9, 2001.

6. CANO, G. et al. Estimation of hormone receptor status in fine-needle aspirates and paraffin-embedded sections from breast cancer using the novel rabbit monoclonal antibodies SP1 and SP2. Diagn Cytopathol, v. 29, n. 4, p. 207-11, 2003.

7. CARLSON, R. W. et al. HER2 testing in breast cancer: NCCN Task Force report and recommendations. J Natl Compr Canc Netw, v. 4, Suppl 3, S1-22, quiz S23-24, 2006.

8. CHEANG, M.C.U. et al. Immunohistochemical detection using the new rabbit monoclonal antibody SP1 of estrogen receptor in breast cancer is superior to mouse monoclonal antibody 1D5 in predicting survival. J Clin Oncol, v. 24, n. 36, p. 5637-44, 2006.

9. COBLEIGH, M. A. et al. Multinational study of the efficacy and safety of humanized anti-HER2 monoclonal antibody in women who have HER2-overexpressing metastatic breast cancer that has progressed after chemotherapy for metastatic disease. J Clin Oncol, v. 17, n. 9, p. 2639-48, 1999.

10. DAKO. DAKO HercepTest: a manual for interpretation. Carpinteria: DAKO, Manual Guideline, 1999.

11. DAKO. DAKO ACIS ${ }^{\text {TM }}$ automated cellular imaging system. Available at: http://www.dakogmbh.de, 2007.

12. DANDACHI, N.; DIETZE, O.; HAUSER-KRONBERGER, C. Chromogenic in situ hybridization: a novel approach to a practical and sensitive method for the detection of
HER2 oncogene in archival human breast carcinoma. Lab Invest, v. 82, n. 8, p. 1007-14, 2002.

13. ELLIS, I. O. et al. Best Practice No 176: Updated recommendations for HER2 testing in the UK. J Clin Pathol, v. 57, n. 3, p. 233-7, 2004.

14. ENMARK, E.; GUSTAFSSON, J-A. Estrogen receptor $\beta$ : a novel receptor opens up new possibilities for cancer diagnosis and treatment. Endocr Rel Cancer, v. 5, p. 213-22, 1998.

15. FITZGIBBONS, P. L. et al. Prognostic factors in breast cancer. College of American Pathologists Consensus Statement 1999. Arch Pathol Lab Med, v. 124, n. 7 , p. 966-78, 2000.

16. GOBBI, H. et al. A comparative study between rabbit monoclonal antibodies and mouse monoclonal antibodies anti-estrogen receptor in breast cancer. Lab Invest, v. 86, p. 28A, 2006.

17. GOBBI H. et al. Breast cancer risk associated with estrogen receptor expression in epithelial hyperplasia lacking atypia and adjacent lobular units. I J Cancer, v. 113, n. 1, p. 857-9, 2005.

18. GOLDHIRSCH, A. et al. Meeting highlights: international expert consensus on the primary therapy of early breast cancer 2005. J Clin Oncol, v. 19, n. 18, p. 3817-27, 2001.

19. GONG, Y.; GILCREASE, M.; SNEIGE, N. Reliability of chromogenic in situ hybridization for detecting HER2 gene status in breast cancer: comparison with fluorescence in situ hybridization and assessment of interobserver reproducibility. Mod Pathol, v. 18, n. 8, p. 1015-21, 2005

20. GOUVEA, A. P. et al. HER-2/neu immunoreactivity in invasive mammary carcinomas: a comparative study using monoclonal and polyclonal antibodies including the HercepTest ${ }^{\text {TM }}$. J Bras Patol Med Lab, v. 40, n. 1, p. 27-32, 2004.

21. GOUVEA, A. P. et al. Selecting antibodies to detect HER2 overexpression by immunohistochemistry in invasive mammary carcinomas. Appl Immunohistochem Mol Morphol, v. 14, n. 1, p. 103-8, 2006.

22. HANNA, W. M.; KWOK, K. Chromogenic in-situ hybridization: a viable alternative to fluorescence in-situ hybridization in the HER2 testing algorithm. Mod Pathol, v. 19, n. 4, p. 481-7, 2006.

23. HARVEY, J. N. et al. Estrogen receptor status by immunohistochemistry is superior to the ligand-binding assay for predicting response to adjuvant endocrine therapy in breast cancer. J Clin Oncol, v. 17, p. 147481, 1999. 
24. HUANG, Z. et al. Development of new rabbit monoclonal antibody to estrogen receptor. Appl Immunohistochem Mol Morphol, v. 13, p. 91-5, 2005.

25. HUANG, Z. et al. Development of new rabbit monoclonal antibody to progesterone receptor (clone SP2): no heat pretreatment but effect for paraffin section immunohistochemistry. Appl Immunohistochem Mol Morphol, v. 14, n. 2, p. 229-33, 2006.

26. HUANG, Z.; ZHU, W.; MENG, Y. Novel rabbit monoclonal antibody to estrogen receptor (clone SP1): no heat pretreatment but effective on paraffin embedded tissue. Appl Immunohistoch Mol Morphol, v. 13, p. 91-5, 2005.

27. JIMENEZ, R. E. et al. Determination of Her-2/Neu status in breast carcinoma: comparative analysis of immunohistochemistry and fluorescent in situ hybridization. Mod Pathol, v. 13, n. 1, p. 37-45, 2000.

28. KOUNELIS, S. et al. Evaluation of HER2 gene status in breast cancer by chromogenic in situ hybridization: comparison with immunohistochemistry. Anticancer Res, v. 25, n. 2A, p. 939-46, 2005.

29. LAMBROS, M. B. K. et al. Unlocking pathology archives for molecular genetic studies: a reliable method to generate probes for chromogenic and fluorescent in situ hybridization. Lab Invest, v. 86, n. 4, p. 398-408, 2006.

30. LAMBROS, M. B. K. et al. Chromogenic and fluorescent in situ hybridization in breast cancer. Hum Path, v. 38, p. 1105-22, 2007.

31. LEHR, H-A. et al. Application of Photoshop-based image analysis to quantification of hormone receptor expression in breast cancer. J Hist Cytochem, v. 45, n. 1, p. 1559-65, 1997.

32. LEONG, A.S-Y. Refinement of immunohistologic parameters for Her2/neu scoring validation by FISH and $\mathrm{CISH}$. Appl Immunohistochem Mol Morphol, v. 14, n. 4, p. 384-9, 2006.

33. LOMBARDO, J. F. American Society of Clinical Oncology/ College of American Pathologists guidelines should be scientifically validated. Arch Pathol Lab Med, v. 131, n. 10, p. 1510, 2007.

34. LORING, P. et al. HER2 positivity in breast carcinoma: a comparison of chromogenic in situ hybridization with fluorescence in situ hybridization in tissue microarrays, with targeted evaluation of intratumoral heterogeneity by in situ hybridization. Appl Immunohistochem Mol Morphol, v. 13, n. 2, p. 194-200, 2005.

35. McCORMICK, S. R. et al. HER2 assessment by immunohistochemical analysis and fluorescence in situ hybridization: comparison of HercepTest and PathVysion commercial assays. Am J Clin Pathol, v. 117, n. 6, p. 935-43, 2002

36. MILLER, R. T.; KUBIER, P. Blocking of endogenous avidinbinding activity in immunohistochemistry: the use of egg whites. Appl Immunohistochem, v. 5, p. 63-6, 1997.

37. MOSKALUK, C. A. Standardization of clinical immunohistochemistry: why, how and by whom? Am J Clin Pathol, v. 118, n. 5, p. 669-71, 2002.

38. NUNES, C. B. et al. Concordância interobservador na interpretação imunohistoquímica da superexpressão do Her2 detectada por cinco diferentes anticorpos em arrays de carcinomas mamários. J Bras Patol Med Lab, v. 43 , n. 5, p. 365-71, 2007

39. PETROSYAN, K.; TAMAYO, R.; JOSEPH, D. Sensitivity of a novel biotin-free detection reagent (powervision+) for immunohistochemistry. J Histotechnol, v. 25, p. 247-50, 2002.

40. PRESS, M. F. et al. Evaluation of HER-2/neu gene amplification and overexpression: comparison of frequently used assay methods in a molecularly characterized cohort of breast cancer specimens. J Clin Oncol, v. 20, n. 14, p. 3095-105, 2002.

41. RHODES, A. et al. Evaluation of HER-2/neu immunohistochemical assay sensitivity and scoring on formalin-fixed and paraffin-processed cell lines and breast tumours: a comparative study involving results from laboratories in 21 countries. Am J Clin Pathol, v. 118, p. 408-17, 2002.

42. RHODES, A. et al. Reliability of immunohistochemical demonstration of oestrogen receptors in routine practice: inter-laboratory variance in the sensitivity of detection and evaluation of scoring systems. J Clin Pathol, v. 53, p. 125, 2000.

43. RICARDO, S. et al. HER2 Evaluation through the novel rabbit monoclonal antibody SP3 and $\mathrm{CISH}$ in tissue microarrays of invasive breast carcinomas. J Clin Pathol, v. 60, p. 1001-5, 2006.

44. ROCHA, R. M. et al. Construção de arrays de tecido com equipamento alternativo e de baixo custo para estudo imunoistoquímico de tumores mamários. J Bras Patol Med Lab, v. 42, p. 477-82, 2006.

45. ROCHA, R. M. et al. Rabbit monoclonal antibodies are highly cost effective and a reliable alternative to mouse antibodies for estrogen and progesterone receptor evaluation of breast cancer by immunohistochemistry. Lab Invest, v. 87, p. 48A, 2007.

46. ROSSI, S. etal. Rabbit monoclonal antibodies: a comparative study between a novel category of immunoreagents and the corresponding mouse monoclonal antibodies. Am J Clin Pathol, v. 124, n. 2, p. 295-302, 2005.

47. SHI, S-R.; COTE, R. J.; TAYLOR, C. R. Antigen retrieval immunohistochemistry: past, present and future. J Histochem Cytochem, v. 45, p. 327-43, 1997.

48. TAFURI, L. S. A. et al. Cell cycle related proteins in hyperplasia of usual type in breast specimens of patients with and without breast cancer. BMC Cell Biol, v. 7, p. 29, 2006.

49. TANNER, M. et al. Chromogenic in situ hybridization: a practical alternative for fluorescence in situ hybridization to detect HER-2/neu oncogene amplification in archival breast cancer samples. Am J Pathol, v. 157, n. 5, p. 1467-72, 2000.

50. THOMSON, T. A. et al. HER-2/neu in breast cancer: interobserver variability and performance of immunohistochemistry with 4 antibodies compared with fluorescent in situ hybridization. Mod Pathol, v. 14, n. 11, p. 1079-86, 2001.

51. UMEMURA, S. et al. Immunohistochemical evaluation of hormone receptor for routine practice of breast cancer: highly sensitive procedures significantly contribute to the correlation with biochemical assays. 
Appl Immunohistochem Mol Morphol, v. 11, p. 62-72, 2003.

52. VINCENT-SALOMON, A. et al. Calibration of immunohistochemistry for assessment of HER2 in breast cancer: Results of the French multicentre GEFPICS study. Histopathology, v. 42, n. 4, p. 337-47, 2003.

53. WANG, S. et al. Laboratory assessment of the status of Her-2/neu protein and oncogene in breast cancer specimens: comparison of immunohistochemistry assay with fluorescence in situ hybridisation assays. J Clin Pathol, v. 53, n. 5, p. 374-81, 2000.
54. WOLFF, A. C. et al. American Society of Clinical Oncology/College of American Pathologists guideline recommendations for human epidermal growth factor receptor 2 testing in breast cancer. J Clin Oncol, v. 25, p. 118-45, 2007.

55. ZHAO, J. et al. Determination of HER2 gene amplification by chromogenic in situ hybridization ( $\mathrm{CISH}$ ) in archival breast carcinoma. Mod Pathol, v.15, n.6, p.657-65, 2002.

56. ZYMED ${ }^{\circledR}$ : Spot-Light ${ }^{\circledR} \mathrm{CISH}^{\mathrm{TM}}$ Probes and $\mathrm{CISH}^{\mathrm{TM}}$ Detection. In. South San Francisco; 2005. 